Int. J. Environ. Sci. Tech.

(C) Supplement Winter 2006, Vol. 3, No. 1, pp. 35-42

\title{
Origin and chemical partitioning of heavy metals in riverbed sediments
}

\author{
${ }^{1 *}$ A. R. Karbassi, ${ }^{1}$ I. Bayati and ${ }^{2}$ F. Moattar \\ ${ }^{1}$ Department of Environmental Science, Graduate School of the Environment and Energy, Islamic Azad University, \\ Science and Research Campus, Tehran, Iran \\ ${ }^{2}$ Radio-isotope Division, Iran Atomic Energy Organization, Tehran, Iran
}

Received 9 January 2006;

revised 5 February 2006;

accepted 25 February 2006

available online 18 April 2006

\begin{abstract}
In the present investigation, bulk and chemical partitioning of elements in the Shefa-Rud riverbed sediments are studies. Higher concentrations of elemental concentrations have been observed in estuarine zone when compared with riverine sediments (except for $\mathrm{Al}, \mathrm{Fe}, \mathrm{Pb}$ and $\mathrm{Mn}$ ). Manganese is mobilized under anoxic conditions prevailing in the Caspian Sea. Lithogenous materials are greatly diluted in the estuarine zone by various pollutants present in the Caspian Sea. Organic metallic bonds are not significantly present in the area of study. Geological units of the area of study have resulted in the lower concentrations of elemental concentrations of riverbed sediments when compared with published values for mean crust and world sediments ones. Though, cluster analysis has clearly shown the importance of alumina-silicates in controlling the distribution of Fe and Mn in riverbed sediments but it could not depict controlling mechanism for other studied elements. Geochemical Index (Igeo) and Enrichment Factor (EF) values are indicative of a clean environment throughout the river course. These values are in a well agreement with results of chemical partitioning data. Quantification of EF values is not logically possible and therefore Igeo values can be used more effectively.
\end{abstract}

Key words: Geochemistry, sediment, elements, Igeo, enrichment factor

*Corresponding Author, E-mail:karbassi@iranenergy.org.ir

\section{INTRODUCTION}

Human activities have lead to accumulation of toxic metals in the aquatic sediments (Yang and Rose, 2003; Heyvaert et al., 2000). Sediments and suspended particulate matters (SPM) of aquatic environment have an important role in adsorption of dissolved heavy metals, although they can be a potential source of metal pollution by releasing adsorbed metals during changing physical-chemical characteristics of the aquatic environment. Since concentrations of most heavy metals in river waters are very low and subject to highly variations during a year, sediments and SPM are good indicators of metal pollution in the river environment. Trace element pollution in rive, lake, estuary and bay sediments caused by industrialization has been reported by many researchers around the world (Al-Masri, 2002; Coker et al., 1995; Farmer, 1991). Forstner and Muller (1973) used a sediment pollution index to evaluate the heavy metal pollution of rivers of Germany. Geochemical studies of sediment are helpful in the assessment of pollution (Holm, 1988). Most trace metals tend to enrich in the modern organic sediments rather than inorganic sediments. Many researchers have used sediments to study the behavior of metals over time of sedimentation (Bellucci et al., 2003; Bertolotto et al., 2003; Al-Masri et al., 2002; Borretzen and Salbu, 2002; Weis et al., 2001; Lee and Cundy, 2001; Karbassi, 1989). Chemical bonds of metals in sediments and SPM is an important factor in detecting pollution in the particulate phase of the river. Many sequential extraction and chemical partitioning methods have been developed and applied for determination of metal bonding and pollution detection in particulate phase (Chester and Hughes, 1967). It is believed that metals in adsorbed, carbonate, sulfide and organic bonds are more related to pollution and have higher risk of bioavailability and contamination of the environment.

There are many rivers flowing into the Caspian Sea via its southern coast through northern part of Iran that are ecologically of significant importance considering the Caspian Sea environment (e.g. ShefaRud, Chaloos, Haraz, Babol, Talar, Tadjan and GorganRud). Most of these rivers are used as transport agents for the disposal of industrial, agricultural and urban 
wastes. Therefore, it is essential to closely investigate the overall geochemical cycle of trace metals and their behavior in this region. In the present investigation speciation of trace metals in Shefa-Rud river-bed sediments have been studied during 2005-2006.

Shefa-Rud River flows into the Caspian Sea from Northern part of Iran. The catchments area of this river is about $350 \mathrm{Km}^{2}$. The length of Shefa-Rud river is about $34.5 \mathrm{Km}$ with average slope of $7.7 \%$ and water discharge of $180 \times 10^{6} \mathrm{~m}^{3} / \mathrm{yr}$.

It is one of the most important rivers in the view of fisheries. Though most of rivers in the northern part of Iran are used as means of pollution carriers; exceptionally Shefa-Rud River has remained intact. Thus, it can provide ample opportunity to investigate on chemical partitioning studies of elements before any pollution occurrence and also in evaluation of various environmental indices such as Geochemical Index (Igeo) and Enrichment Factor (EF).

\section{MATERIALS AND METHODS}

Riverine and estuarine sediments were collected from Shefa-Rud River in winter 2004 using Peterson grab sampler. Location of samples is shown in Fig. 1. The riverbed sediments are brownish clayey silts deposited in the recent times. Sediments were dried at $70^{\circ \mathrm{C}}$ for 24hrs and passed through mesh smaller than 63 micron meter. The sediment grains were then powdered using an agate mortal and pestle. Bulk digestion was carried out by $\mathrm{HF}-\mathrm{HNO}_{3}-\mathrm{HCl}-\mathrm{HClO}_{4}$. Chemical partition studies were carried out in four sequential steps: 1 ) acetic acid $25 \% \mathrm{v} / \mathrm{v}$; 2) acetic acid 25\% v/v- 0.1M hydroxylamine hydrochloride; 3) $30 \% \mathrm{H}_{2} \mathrm{O}_{2}$ "extraction with $1 \mathrm{M}$ ammonium acetate” and 4) hot 50\% $\mathrm{HCl}$ (Chester and Hughes, 1967; Malo, 1977; Gibbs, 1973; Gupta and Chen, 1975). Metal concentrations were measured by VARIAN TECHTRO AA-5 at the university of Science and Technology, Tehran, Iran, in spring 2005. Procedural blanks and duplicates were run with the samples in a similar way for quality assurance of the laboratory analysis.

The accuracy of analysis was about $\pm 6 \%$ for all elements. A standard sample (MESS-1) was analyzed in the same manner for analysis accuracy check. Results showed that the errors in the analysis were $<5 \%$.

\section{RESULTS}

Concentrations of $\mathrm{Cu}, \mathrm{Ni}, \mathrm{Pb}, \mathrm{Co}, \mathrm{Zn}, \mathrm{Mn}, \mathrm{Fe}, \mathrm{Al}, \mathrm{Ca}$ and organic matter as loss in ignition (LOI) in river-bed sediments of Shefa-Rud are presented in Table 1. A close look on the data shows that concentrations of $\mathrm{Cu}$ and $\mathrm{Ni}$ almost tally with the average concentrations of World Sediments. However, concentrations of the other studied elements (except for $\mathrm{Pb}$ ) are considerably lower

Table 1: Concentrations of metals and organic matters in Shefa-Rud river-bed sediment

\begin{tabular}{|c|c|c|c|c|c|c|c|c|c|c|}
\hline & LOI & $\mathrm{Ca}$ & $\mathrm{Al}$ & $\mathrm{Fe}$ & $\mathrm{Mn}$ & $\mathrm{Zn}$ & Co & $\mathrm{Pb}$ & $\mathrm{Ni}$ & $\mathrm{Cu}$ \\
\hline 1 & 3.5 & 1.1 & 4.1 & 2.5 & 520 & 56 & 10 & 20 & 49 & 33 \\
\hline 2 & 3.2 & 1.2 & 4.2 & 2.5 & 510 & 58 & 10 & 20 & 48 & 34 \\
\hline 3 & 3.6 & 1.1 & 4.1 & 2.5 & 515 & 59 & 9 & 20 & 50 & 34 \\
\hline 4 & 3.4 & 1.3 & 4.1 & 2.5 & 517 & 58 & 8 & 20 & 49 & 35 \\
\hline 5 & 3.2 & 1.2 & 4.2 & 2.4 & 512 & 59 & 11 & 21 & 51 & 34 \\
\hline 6 & 3.3 & 1.2 & 4.2 & 2.6 & 514 & 57 & 10 & 20 & 51 & 36 \\
\hline 7 & 3.6 & 1.2 & 4.1 & 2.4 & 500 & 59 & 10 & 20 & 50 & 35 \\
\hline 8 & 5.2 & 1.9 & 3.3 & 1.9 & 440 & 66 & 12 & 21 & 58 & 41 \\
\hline Min. & 3.2 & 1.1 & 3.3 & 1.9 & 440 & 56 & 8 & 20 & 48 & 33 \\
\hline Max. & 5.2 & 1.9 & 4.2 & 2.6 & 520 & 66 & 12 & 21 & 58 & 41 \\
\hline S. D. & \pm 0.66 & \pm 0.27 & $\boxplus 0.3$ & \pm 0.2 & \pm 26 & \pm 3.0 & $\# .2$ & $\boxplus 0.46$ & \pm 3.1 & \pm 2.5 \\
\hline $\begin{array}{c}\text { Mean of } \\
\text { present study }\end{array}$ & 3.63 & 1.28 & 4.04 & 2.41 & 503.5 & 59 & 10 & 20.25 & 50.75 & 35.25 \\
\hline Mean Crust * & - & 4.1 & 8.2 & 4.1 & 950 & 75 & 20 & 14 & 80 & 50 \\
\hline $\begin{array}{c}\text { Mean World } \\
\text { Sediments* }\end{array}$ & 一 & 6.6 & 7.2 & 4.1 & 770 & 95 & 14 & 19 & 52 & 33 \\
\hline
\end{tabular}

*Bowen, 1979 
Origin and chemical partitioning...

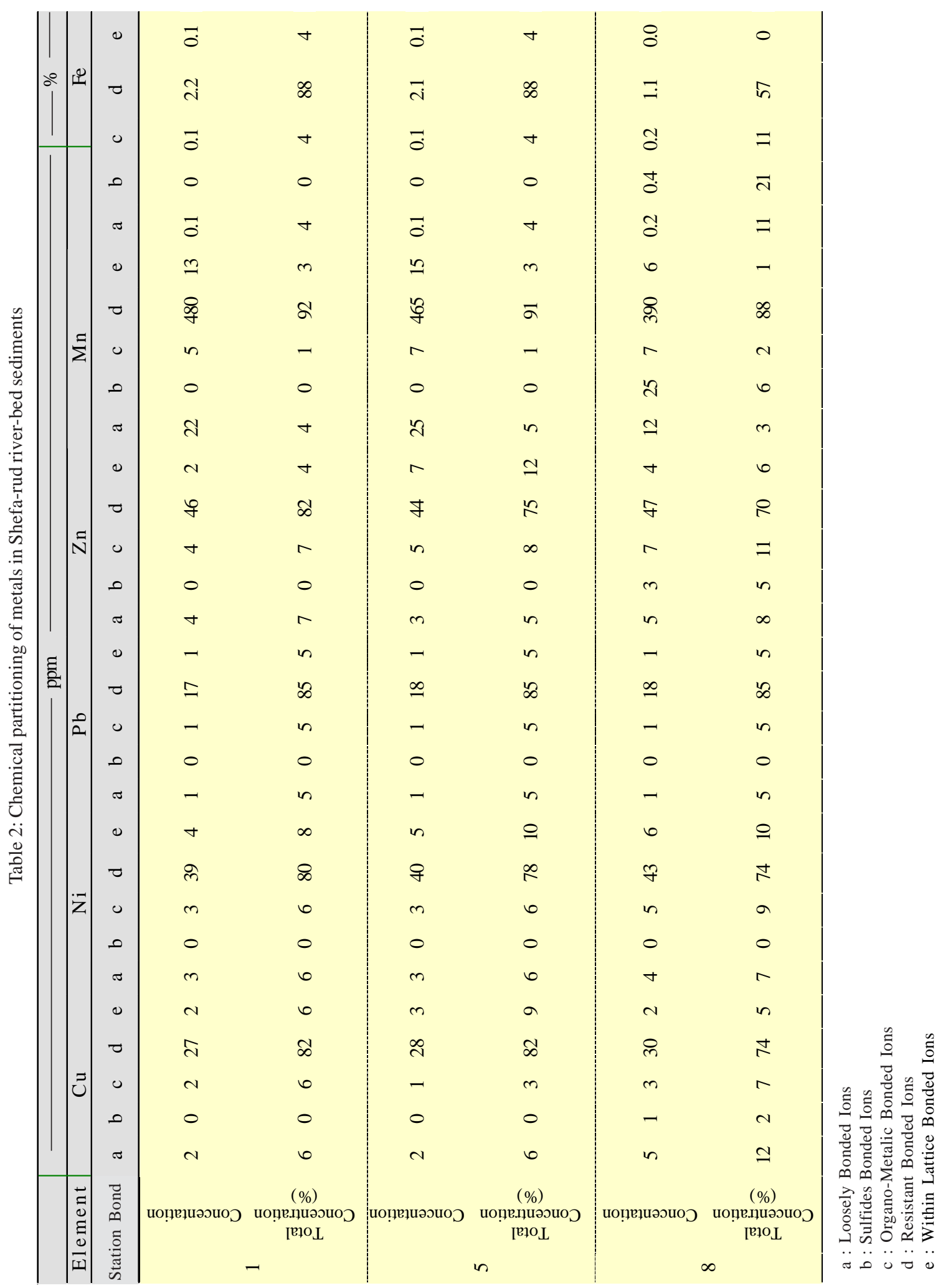


Table 3: Comparison of Igeo and EF values for metals in sediments of Shefa-rud river

\begin{tabular}{|c|c|c|c|c|c|c|c|c|c|}
\hline \multirow[t]{2}{*}{ Elements } & \multicolumn{3}{|c|}{ Igeo } & \multicolumn{3}{|c|}{ EF } & \multicolumn{3}{|c|}{$\begin{array}{c}\text { Anthropogenic } \\
\text { portion (\%) }\end{array}$} \\
\hline & St.1 & St. 5 & St. 8 & St.1 & St. 5 & St.8 & St. 8 & St.5 & St.1 \\
\hline $\mathrm{Cu}$ & 0.62 & 0.58 & 0.77 & 1.08 & 1.16 & 1.77 & 22 & 9 & 12 \\
\hline $\mathrm{Ni}$ & 0.61 & 0.61 & 0.67 & 1.00 & 1.09 & 1.56 & 16 & 12 & 12 \\
\hline $\mathrm{Pb}$ & 0.58 & 0.58 & 0.58 & 2.34 & 2.56 & 3.24 & 10 & 10 & 10 \\
\hline $\mathrm{Zn}$ & 0.65 & 0.61 & 0.78 & 1.22 & 1.34 & 1.90 & 24 & 13 & 14 \\
\hline $\mathrm{Mn}$ & 0.58 & 0.58 & 0.58 & 0.90 & 0.92 & 1.00 & 11 & 6 & 5 \\
\hline
\end{tabular}

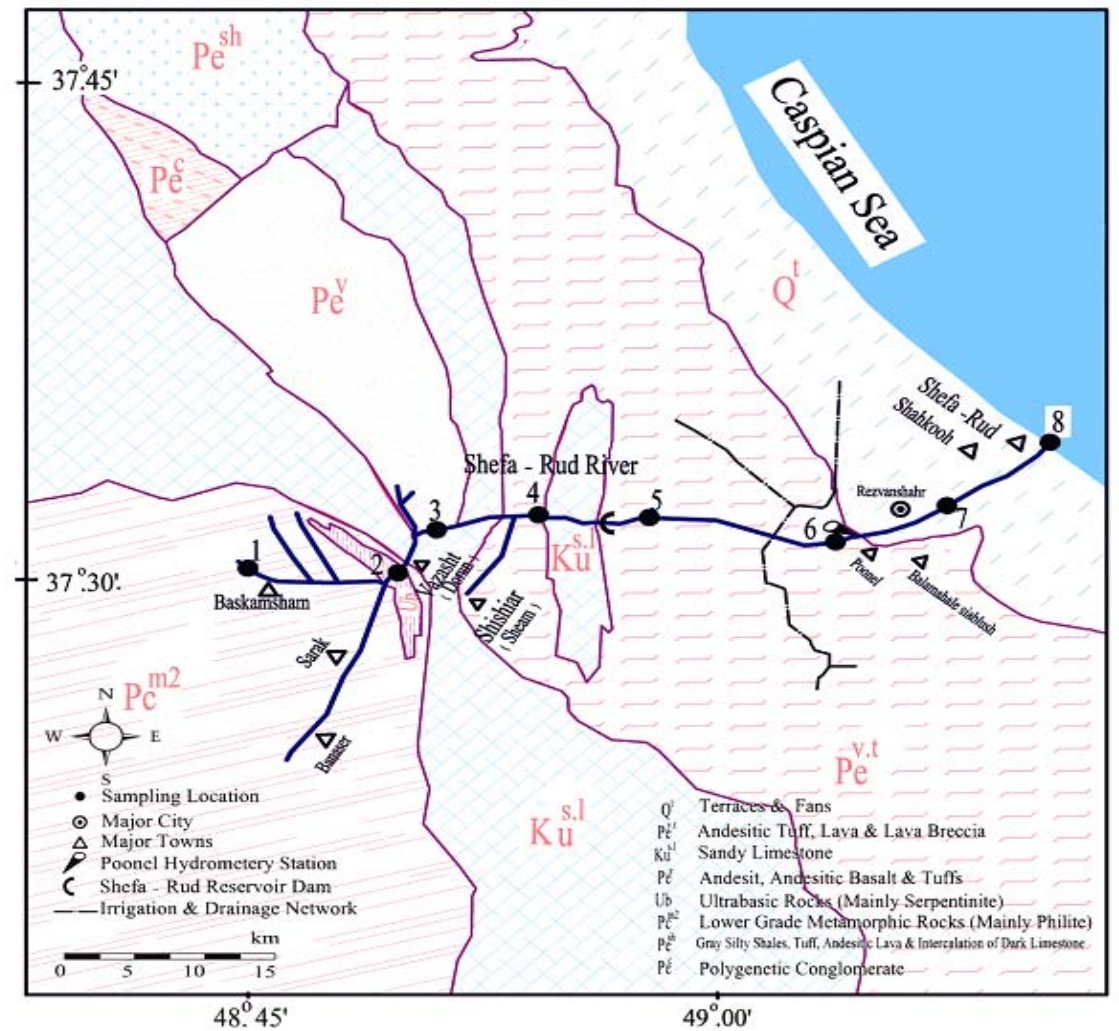

Fig. 1: Location of sediment samples in Shefa-rud river

than the average concentrations of mean curst and World Sediments (Table 1). Such discrepancies between concentrations of elements in the area of study with those of mean crust and mean World sediments are indicative of considerable deviation in geological units. Most of the area of study is covered with tuff and gravel; thus lower concentrations of element could be expected. Further cluster analysis (Davis, 1973) was used to know about inter-relation amongst studied elements. As shown in Fig. 2, Dendrogram of cluster analysis depicts three distinct clusters namely " $A$ ", " $\mathrm{B}$ " and " $\mathrm{C}$ ". There is a large discrepancy between results of cluster analysis and those of chemical partitioning studies. For instance chemical partitioning studies does not show considerable affinity amongst studied metals and organics (Table 2). The results of chemical partitioning studies were grouped into lithogenous and anthropogenic ones (Fig. 3). Finally, pollution intensity was subjected to Igeo and EF analysis (Table 3 ). The Igeo and EF values are compared with the percentile of pollution obtained from chemical partitioning studies.

Percentile of elements in various sedimentary phases can be summarized as follows: 
Loose ions: $\mathrm{Cu}(8 \%)>\mathrm{Zn}(6.5 \%)>\mathrm{Ni} \& \mathrm{Fe}(6 \%)>\mathrm{Pb}$ (5\%) > Mn (4\%);

Sulfide ions: $\mathrm{Fe}(7 \%)>\mathrm{Mn}(2 \%)>\mathrm{Zn}(1.5 \%)>\mathrm{Cu}(0.7 \%)$ $>\mathrm{Pb} \& \mathrm{Ni}(0.0 \%)$;

Organic ions: $\mathrm{Zn}(8.5 \%)>\mathrm{Ni}(7 \%)>\mathrm{Fe}(6 \%)>\mathrm{Cu} \& \mathrm{~Pb}$ $(5 \%)>$ Mn (1\%);

Resistant ions: $\mathrm{Mn}(91 \%)>\mathrm{Pb}(85 \%)>\mathrm{Cu}(79.1 \%)>\mathrm{Fe}$ $(78 \%)>\mathrm{Ni}(77 \%)>\mathrm{Zn}(76.1 \%)$ and

Within lattice ions: $\mathrm{Ni}(10 \%)>\mathrm{Zn}(7.4 \%)>\mathrm{Cu}(7 \%)>\mathrm{Pb}$ $(5 \%)>\mathrm{Fe}(3 \%)>\mathrm{Mn}(2 \%)$.

As mentioned earlier, in spite of results of cluster analysis, little portions of studied metals are incorporated into organic-metallic bonds. Here, Zn shows more affinity towards organics when compared with other metals. Presence of Fe and $\mathrm{Mn}$ in sulfide fraction (at estuarine zone) might be indicative of initial stages of conversion of oxidation state into reducing one (Karbassi, 1996) in the Caspian Sea. Further the results of chemical partitioning were grouped into anthropogenic and lithogenous ones. As shown in Fig.3, share of anthropogenic sources in the contribution of elements increases substantially at estuarine zone, except for $\mathrm{Pb}$ that remains constant throughout all sampling stations. Quantification of EF is not possible though their values were simultaneously compared with Igeo values as well as anthropogenic portion obtained from chemical partitioning studies. For instance, $\mathrm{Pb}$ with Igeo value of 0.56 in all the three stations (indicative of non pollution environment) and $10 \%$ anthropogenic portion which is constant through out stations 1, 5 and 8 (upstream to estuarine zone) possess EF value of 2.34, 2.56 and 3.24 in the same stations. On the other hand, Zn with higher Igeo values (ranging from 0.61 to 0.78 ) and 14, 13 and 24\% anthropogenic portion in stations 1,5 and 8 respectively, possess EF values of 1.22, 1.34 and 1.90 in the same stations. Though based on chemical partitioning studies one could expect higher EF values for $\mathrm{Zn}$ than $\mathrm{Pb}$, such expectation was not observed.

\section{DISCUSSION AND CONCLUSION}

Geological units in the area of study have totally governed the concentration of trace metals (except for $\mathrm{Cu}$ and $\mathrm{Ni}$ ) much lower than mean crust and World Sediments. Though cluster analysis has been frequently and meaningfully used by various researchers (Karbassi, 2004, 1996, 1993 and 1989; Saeedi et al., 2004) to know about relationship amongst various metals and environmental indicators, we have not arrived at such conclusions in the present investigation (except for $\mathrm{Mn}$ and $\mathrm{Fe}$ ). There is a large discrepancy between results of cluster analysis and those of chemical partitioning studies. For instance chemical partitioning studies does not show

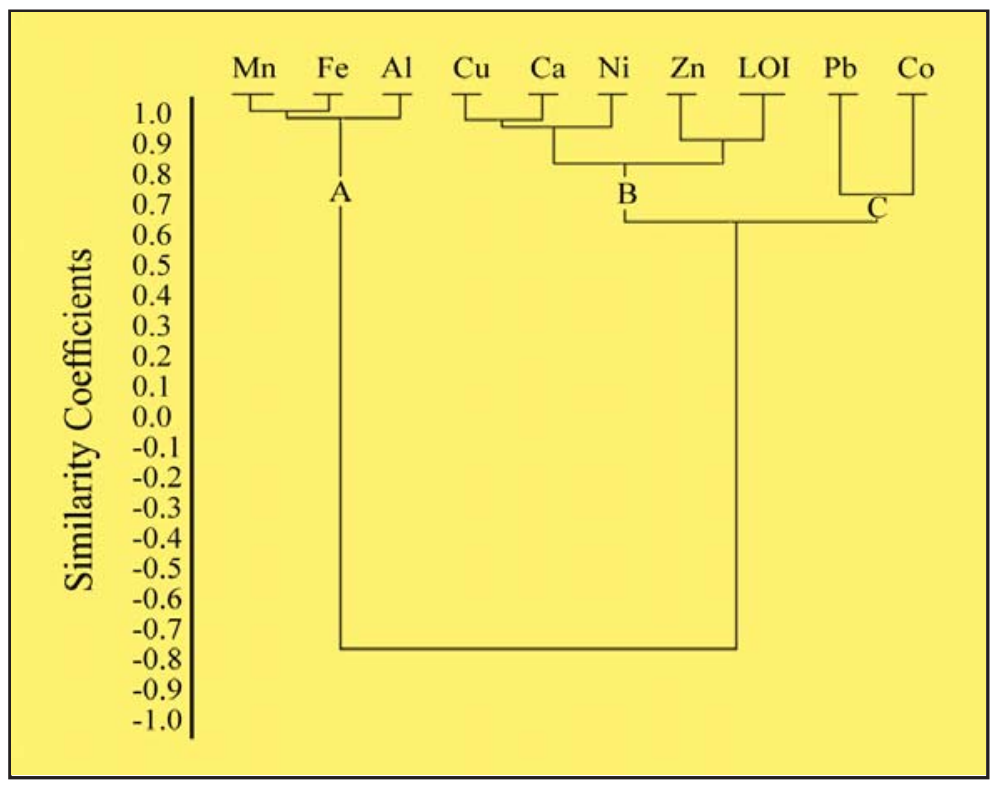

Fig. 2: Dendrogram of cluster analysis for metals in Shefa-rud river-bed sediments 
A. R. Karbassi, et al.
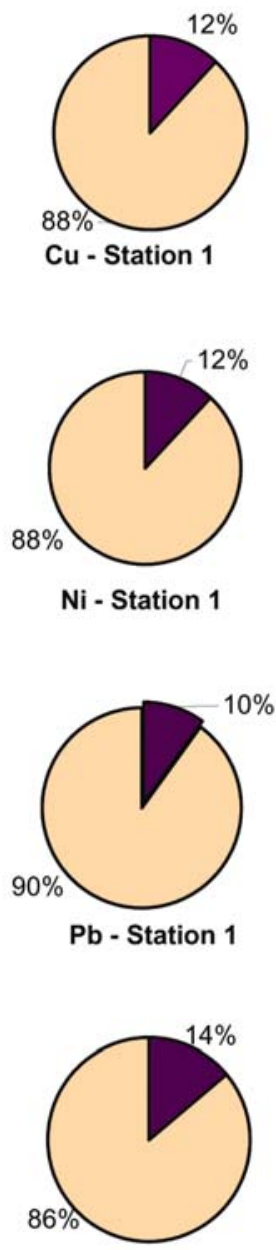

Zn - Station 1
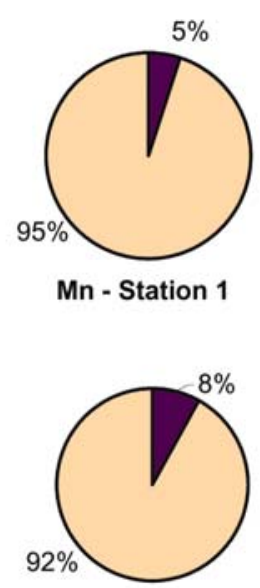

Fe - Station 1
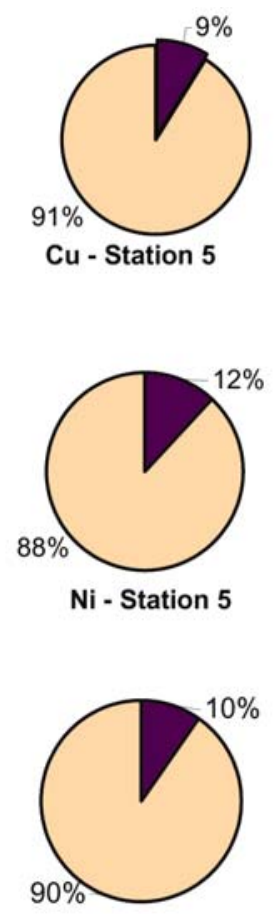

$\mathrm{Pb}$ - Station 5

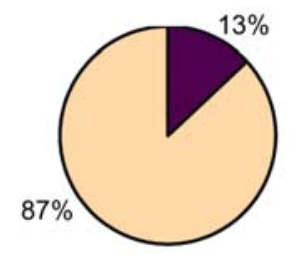

Zn - Station 5
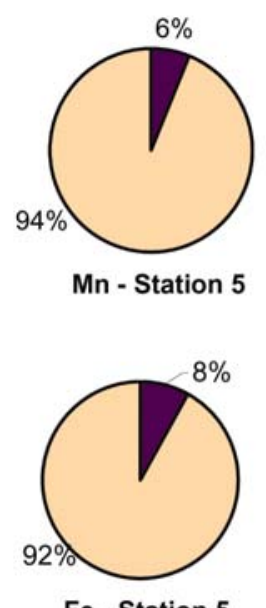

$\mathrm{Fe}$ - Station 5
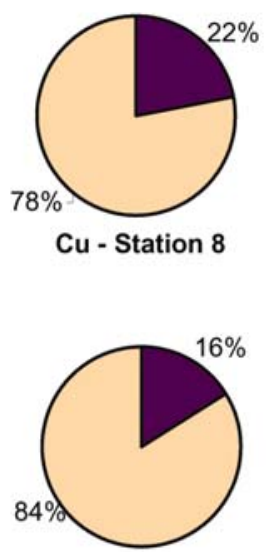

Ni - Station 8

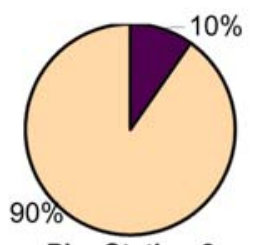

$\mathrm{Pb}$ - Station 8

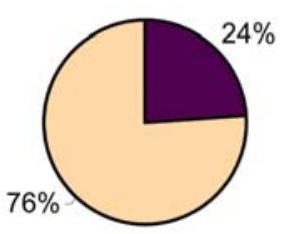

Zn - Station 8

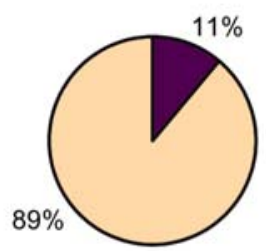

Mn - Station 8

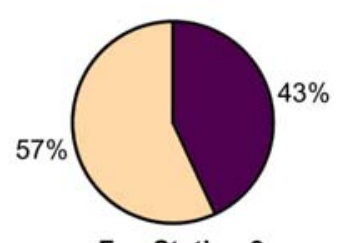

Fe - Station 8

\section{Anthropogenic $\square$ Lithogenous}

Fig. 3: Lithogenous and anthropogenic portions of trace metals in the bed sediments of shefa-rud river 
considerable affinity amongst studied metals and organics. Considering $\mathrm{Al}$ as an indicator of aluminasilicate source, the elements $\mathrm{Mn}$ and Fe might have been incorporated into the riverine sediments from the same source. Copper, $\mathrm{Ca}, \mathrm{Ni}, \mathrm{Zn}, \mathrm{Pb}$ and $\mathrm{Co}$ is not originated from alumina-silicate source. Though $\mathrm{Cu}$, $\mathrm{Ca}, \mathrm{Ni}$ and $\mathrm{Zn}$ show significant affinity toward organics in the cluster analysis but they are not originated from organic sources as shown in chemical partitioning studies.

Geochemical Index (Igeo) and Enrichment Factor (EF) values are indicative of a clean environment throughout the river course. These values are in a well agreement with results of chemical partitioning data. Based on the obtained results it can be inferred that quantification of EF values is not logically possible and therefore Igeo values can be used more effectively. Variation of Igeo and anthropogenic is more meaningful (correlation coefficient $>0.8$ ).

\section{REFERENCES}

Al-Masri, M. S., Aba, A., Khalil, H. and Al-Hares, Z., (2002). Sedimentation rates and pollution history of a dried lake: Al-Oteibeh Lake. Sci. Total Env., 293 (1-3), 177-189.

Bellucci, L. G., El Moumni, B., Collavini, F., Frignani, M. and Albertazzi, S., (2003). Heavy metals in Morocco Lagoon and river sediments. J. de Phys., IV 107 (1), 139-142.

Bertolotto, R. M., Tortarolo, B., Frignani, M., Bellucci, L. G., Albanese, S. and Cuneo, C., (2003). Heavy metals in coastal sediments of the Ligurian sea off Vado Ligure. Journal de Phys., IV 107 (1), 159-162.

Borretzen, P. and Salbu, B., (2002). Fixation of Cs to marine sediments estimated by a stochastic modeling approach. J. Environ. Radioactive., 61 (1), 1-20.

Bowen, H. J. M., (1979). Environmental Chemistry of the Elements. Academic Press, London, England, 333.

Chester, R., and Hughes, R. M., (1967). A chemical technique for the separation of ferromanganese minerals, carbonate minerals and adsorbed trace elements from Pelagic Sediments, Chem. Geol., 2, 249-262.

Coker, W. B., Kettles, I. M. and Shilts, W. W., (1995). Comparison of mercury concentrations in modern lake sediments and glacial drift in the Canadian Shield in the region of Ottawa/Kingston to Georgian Bay, Ontario, Canada: Water, Air and Soil Poll. 80, 1025-1029.

Davis, J. C., (1973). Statistics and Data Analysis in Geology. Wiley International, New York.

Farmer, J. G., (1991). The perturbation of historical pollution records in aquatic systems: Environ. Geochem. Health, 13 (2), 76-83.

Gibbs, R. J., (1973). Mechanisms of trace metal transport in rivers. Science. 180, 71-72.

Gupta, K. S., and Chen, K. Y., (1975). Partitioning of trace metals in selective chemical fractions of near shore sediments, Environ. Lett., 10, 129-159.

Heyvaert, A. C., Reuter, J. E., Sloton, D. G. and Goldman, C. R., (2000). Paleo-limnological reconstruction of historical atmospheric lead and $\mathrm{Hg}$ deposition at lake Tahoe, California-Nevada. J. Environ. Sci. Tech., 34, 3588-3597.

Holm, N. G., (1988). Arsenic regeneration from estuarine sediments of the Bothnian Bay, Sweden. J. Chem. Geol., 68, 89-98.

Karbassi, A. R., (1989). Geochemical and magnetic studies of riverine, estuarine and marine sediments. Ph.D. thesis, Mangalore University, India, 196.

Karbassi, A. R., (1993). Geochemistry of a sediment core and applications of analysis in interpret ting data. The $16^{\text {th. }}$ Intl. Geo. Expl. Symp. Beijing, China.

Karbassi, A. R., (1996). Geochemistry of Ni, Zn, Cu, Pb, Co, $\mathrm{Cd}, \mathrm{V}, \mathrm{Mn}, \mathrm{Fe}, \mathrm{Al} \& \mathrm{Ca}$ in sediments of North Western part of the Persian Gulf. Intl. J. Env. Studies., 54, 205-212.

Karbassi, A. R. and Amirnezhad, R., (2004). Geochemistry of heavy metals and sedimentation rate in a bay adjacent to the Caspian Sea. Int. J. Env. Sci. Tech., 1 (3), 199-206.

Lee, S. V. and Cundy, A. B., (2001). Heavy metal contamination and mixing processes in sediments from the Humber Estuary, Eastern England. Estuarine Coastal and Shelf Sci. 53 (5), 619-636.

Malo, B. A., (1977). Partial extraction of metals from aquatic sediments. J. Env. Tech. 11, 277-282.

Weis, D. A., Callaway, A. B. and Gersberg, R. M., (2001). Vertical accretion rates and heavy metal chronologies in wetland sediments of the Tijuana Estuary. Estuaries, 24(6A), 840-850.

Yang, H. and Rose N. L., (2003). Distribution of Hg in the lake sediments across the UK, Sci. Total Environ., 304, 391404. 
A. R. Karbassi, et al.

\section{AUTHOR(S) BIOSKETCHES}

Karbassi, A. R., B.Sc., M.Sc., Ph.D., is a lecturer in the Department of Environmental Science, Graduate School of the Environment and Energy, Islamic Azad University, Science and Research Campus, Tehran, Iran and also Managing Director of Iran Energy Efficiency Organization, Tehran, Iran.E-mail: karbassi@iranenergy.org.ir

Bayati, I., B.E., is a student of M.Sc. in the Department of Environmental Science, Graduate School of the Environment and Energy, Islamic Azad University, Science and Research Campus, Tehran, Iran.E-mail: bayati id@yahoo.com

Moattar, F., B.Sc., M.Sc., Ph.D., is a lecturer in the FDepartment of Environmental Science, Graduate School of the Environment and Energy, Islamic Azad University, Science and Research Campus, Tehran, Iran and also senior expert in the Iran Atomic Energy Organization,Tehran, Iran.

E-mail: moattar@yahoo.com

\section{This article should be referenced as follows:}

Karbassi, A. R., Bayati, I. and Moattar, F., (2006). Origin and chemical partitioning of heavy metals in riverbed sediments. Int. J. Environ. Sci. Tech., 3 (1), 35-42. 